\title{
State Education System with e-learning in Nepal: Impact and Challenges
}

\author{
Subarna Shakya ${ }^{1}$, Gajendra Sharma ${ }^{2}$, Kamal B. Thapa ${ }^{3}$ \\ ${ }^{1}$ Department of Electronics and Computer Engineering, Pulchowk Campus, Tribhuvan University, Nepal \\ ${ }^{2,3}$ Department of Computer Science and Engineering, Kathmandu University, Dhulikhel, Kavre, Nepal \\ Corresponding author:drss@ioe.edu.np,gajendra.sharma@ku.edu.np
}

Received: Oct 3, $2017 \quad$ Revised: Dec 13, $2017 \quad$ Accepted: Dec 18, 2017

\begin{abstract}
Education system is upgrading these days with advance technologies that are from conventional learning to E-learning and this is relevant for learner as it is providing flexibility in learning with optional choices for study to the learner with unlimited access of information. E-learning is the effective tools of teaching and learning process these days and different universities of Nepal also broadly adopting this E-learning strategy and offering for distance education or online learning. Here we study the educational situation of rural areas of Nepal comparing to urban areas as well as the barriers of E-learning. The purpose of this paper is to show the changing of learning process from the conventional learning to E-learning in the rapidly changing world and to provide a view of the state of E-learning in Nepal focusing on impact and challenges. It aims to integrate a review of literature to provide a high level comparative view of the state of education system with E-learning. From the studies of all these, we will find the impact and challenges of E-learning as well as why the higher educational institute broadly adopting the E-learning strategy.
\end{abstract}

Keywords: E-learning, distance learning, conventional learning, impact and challenges

\section{Introduction}

As the time has been changing day by day, many technological progress can be seen these days. With the invention of many advanced technological medias like computer, internet, mobile and so on, many bulk of message or information can be send or receive these days making easy for human communication [20]. These kind of sources has made the easy getting information of the things around the world. As a result, with due technological advancement people can easily access the important message or information and can easily solve any problem with in a short period and also has broadened the mind of people thinking increasingly. Before 21 st century, people had to do more effort in getting necessary information. In fact, at that time they required to know which sources provide the reliable information and even if they knew the sources that might not be available. Now this is 21 st century and now everything has changed with the advanced development of technology. We don't need to go anywhere to find any information of thing, just we need to do is that just turn on our computer and browse the browser and type the information required. Then, 
within a short time and less cost that our required information will be in our computer screen. Most of finding these information depends on internet accessibility rather than person's location. Due to advancement of modern technology, people have become more mobility to do multiple task in the world. And also this modern technology has broadened teaching and learning process with E-learning approaches [20]. The transformation can be seen in conventional way of learning to E-learning with the arrival of information technology and its growing use in educational sector [3].

Today's student use the information and communication technology as the tools for learning information. By this, they acquire more information informally and formally with E-learning comparing conventional learning. Conventional learning is different process of learning comparing E-learning as it is teacher centered learning and in conventional learning, the contents or reading materials were provided by the teacher which every students have to study the same topic at the same time provided by the teacher. However in E-learning, contents were largely available and students can have flexibility of learning with optional topic they desire and it is learner centered instructional strategy which provides students the opportunity for self paced learning [3]. Observing the technique of both learning strategy, E-learning has no limitation of accessing information which the conventional learning limited accessing the information for the students. Now, we see most of the universities upgrading the educational system and applying the step-up education with E-learning approach from conventional learning approach that are helping for distance learning. So, by this we can say E-learning as for distance education [20]. Today's advance technology is more helpful for creating educational material including text, images, audio and video that are helping educator for creating good learning environment improving communication and interacting with students. So, E-learning tools has been using more adequately for teaching and learning processes [3]. E-learning is the key of learning with web based technology and other electronic materials. Internet is the main sources of information and these days internet is available everywhere. The term E-learning simply occurs at the computer generally with the internet via browser [19]. This E-learning has made easy learning with low cost for the students and also has made trainer or teacher easy for training and teaching. In this era of 21 st century, the world has changed with new technology and we too. With this era of technology, learning process is no longer limited [2]. Comparing to conventional learning courses, learner can have diverse courses in E-learning [1]. According to Al-Hassan [1], "E-learning comes at the beginning of transformation how individual learn and how they use learning in practice also with the accelerating pace of knowledge growth and change as well as the increasing pressure of the market place made the researcher to look for the innovative learning".

Objective of the study and research question: The main objective of this research paper was to explore the E-learning practices of students in Nepal with the innovation of new teaching and learning technology in a rapidly changing world. As higher educational institute of Nepal are largely adopting the newly emerging learning approach that is E-learning approach, we also study that the state of education system in Nepal with E-learning focusing on impact and challenges.

This study was designed to answer the following research questions:

1) What are the impact and challenges of E-learning in Nepal?

2) Why the higher educational institute broadly adopting the E-learning strategies these days?

\section{Background of e-Learning in Nepal}

As looking backward history of Education in Nepal, there was a traditional culture of learning i.e. Gurukul system where students used to get knowledge and information and learn skill through 
their Guru at Guru's Ashram or temple. And now with due emerging technologies of learning in Nepal, learning system is going changing with new approach i.e. online learning which is as a form of distance learning and E-learning is helping distance learning as it is the broader concept of learning with electronic materials [16]. E-learning or Electronic learning is the process of acquiring knowledge through electronic material or contents in a web based technologies. Earlier education system has used somehow different multimedia CDs and DVDs as E-learning in Nepal. Now in this era of 21st century everything have changed and brought new way of learning with information and communication technologies i.e. with computer and internet which is the best means of acquiring new knowledge or information these days. These ICT tools are the best way of communicating information with anyone else at different location using internet. The E-learning technologies that were mostly used are multimedia CD-ROMs, Web based content or materials, website, blog, wiki, email etc [2].

In earlier, students were only used to learn with face to face approaches using textbooks or from teacher with use of chalk and blackboard as a teaching and learning material. And there is limitation of learning as teacher has fixed teaching schema of the course. These days, students can use different learning materials including computer with internet, web based tools, e-books, smartboard in place of blackboard, audio and video with projector, animated objects etc. Now Nepal is going on the way to new innovative technology with flourishing of education system following new learning strategy i.e. E-learning and there is no limitation of learning for the students. Now different higher education institutions or universities of Nepal has brought the new learning approaches online learning as E-learning for the students to assist teaching and learning processes. An e-learning tool has brought many changes in education system with higher opportunities for both teacher and student. Now in Nepal, learning process has been made more flexible and some of the flexible approaches are online or distance learning. The two most leading universities of Nepal i.e., Tribhuvan University and Kathmandu University are offering these approaches of learning these days for bachelor degree and master degree. Also some of the outside universities are establishing the open distance education in Nepal and so by this reason the E-learning strategy is increasing rapidly in Nepal [16]. Indeed, the spreading of the ICT technologies have created a great influence towards emerging of new learning technology called E-learning. This spreading of the ICT technologies were helping for the transfer of knowledge and skill these days. E-learning is the base for training and education combined with information and technology. The training and education both help in learning and will assist in acquiring knowledge where as information and technology both help in knowledge management [13]. According to Docebo [10], "Out of the 122 countries tracked by Ambient Insight Research, only 15 show a positive (more than 15\%) growth rate for self-paced E-learning". Figure 1 shows the state of the E-learning market globally continuing to shift, grow and evolve. Comparatively Nepal is in 6th position showing the positive growth rate for self-paced E-learning. This emerging trends of E-learning market includes social learning, mobile learning, MOOCs etc. Due to globally increasing the E-learning market, many higher educational institute of Nepal were adopting E-learning strategies and running online learning or distance education these days. 


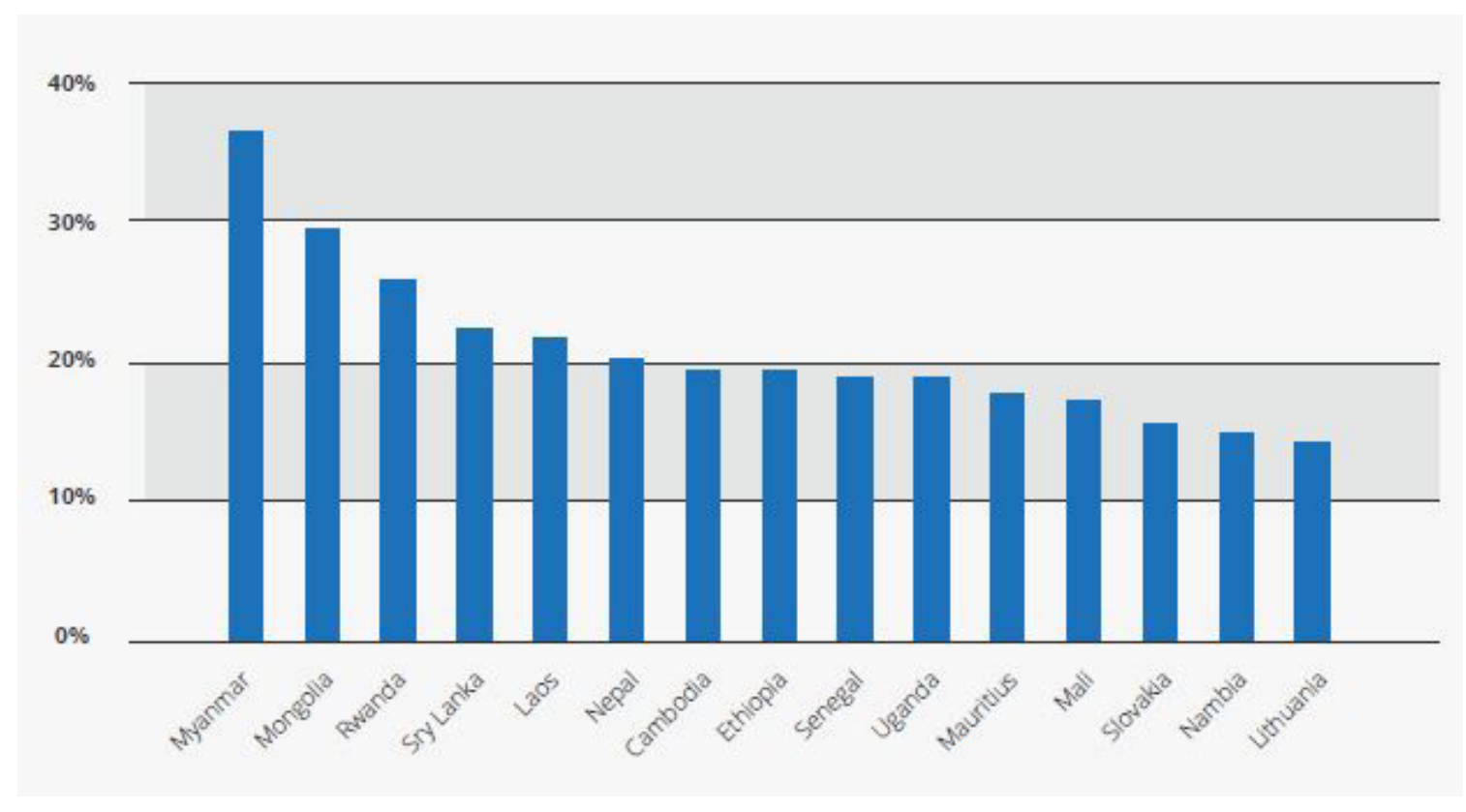

Fig. 1 : 2016-2017 top fifteen worldwide self paced E-learning five year growth rates by country across all product type (Docebo, 2016).

E-learning is becoming the most important topic mattering for higher education since beginning with the web-based course in the mid to late 1990's. The academic leader believes that E-learning is important for the growth of higher educational institutions. Now, students are enabling to enroll in courses or on campuses with the beginning of E-learning but that were not facilitated before for the students. Institutes are now looking different ways of facilitating non-traditional learning [6]. E-learning system for teaching and learning has become more popular in the recent years. More over students were using this phenomena of learning using different E-learning system. One type of E-learning system is Learning management system (LMS) which has become more popular these days. LMS is also called course management system (CMS) or virtual management system (VMS). Nowadays, many universities were broadly adopting this type of learning system with newly emerging system called E-learning system. LMS is web base software that has of distributing learning content making available online over the internet [14]. LMS is the platform that delivers this E-learning to users by which user can log on and can select different courses they want with complete assessment. Asian Development Bank [4] determined that "this LMS is concerned with the development of tools for resources and courses". This LMS system is now enhancing the teaching technique of teacher and also helping organize learning groups and track learner activities, support sequenced and customized learning programs.

Distance education with internet technology helping Nepalese students for multiple option offlexible learning. These days, students using the internet can access worldwide educational opportunities enrolling in MOOC (Massive Open Online Courses) [16]. According to Pangeni [16] "seeing country report of Alison on April first 2016, one of MOOCs states that 29,841 students from Nepal have been educating enrolling on one or more courses and there were 296,031 sessions in Nepal and 750 courses were learned by Nepali students and Nepal is ranking 31 out of 250 countries participating the courses offered by the ALISON". So by this we can say that Nepalese students 
are ready to grab the opportunities of flexible learning option using the internet technology at their own place. Digital Learning for Development (2016) [16], determined that being Nepal a poorest country in the world, Nepal has a literacy rate of $63.9 \%$ and out of 31 million people living in a country only 3.8 million people are familiar with the internet and people living in the urban areas are much familiar with new technologies and those who are enrolled at university know about the MOOC, before no university of Nepal has Offered MOOC to date (MOOC for Higher Education in Nepal). Now the Kathmandu University of Nepal offering the students easy enrollment for the courses online and it is providing free courses available over the internet. Basically MOOC is for flexibility of learning as it provide the different courses and has facility of self enrollment of interesting topic. According to [5], "the reason why the people are registered in MOOCs platform are they would like to be educated in the field or topic they are interested in; second they would like to have a certificate while applying for a job".

\section{Methods of e-Learning}

In today's E-learning environment, the type of learning basically divides into two methods : Synchronous and Asynchronous. Both the strategies have their own pros and cons of learning.

\subsection{Asynchronous e-learning}

Asynchronous E-learning is the flexible type of E-learning, commonly facilitated by media such as web, email and discussion board that support for teacher and learner for teaching and learning even when they are not online at the same time. This type of learning can be carried out when teacher and students both are offline [12]. According to Hrastinski [12], "Asynchronous learning makes it possible for learners to log on to an E-learning environment at any time and download the documents for their study and can send message to the teacher or peers". As there is no worry to course scheduling conflict, students can run their learning at their own pace. This would be the perfect option of learning those who were busy with their own work, family and other commitments. However, asynchronous learning can also lead to feeling of isolation as there are no interactive learning environments available.

\subsection{Synchronous e-learning}

Synchronous E-learning is the type of E-learning commonly facilitated by media such as online chat and video conferencing which has the potential to support to e-learners. In this type of learning, students are able to interact with their friends and teachers that make easy questioning and answering the questions immediately which help avoid frustration [12]. Synchronous learning enable students to avoid feeling of isolation as they can continue communication with others throughout the learning process. However comparing to asynchronous learning, synchronous learning is not the flexible type of E-learning as student have to set a specific time to attend online courses in real time [11]. This would not be perfect learning as it is no ideal for those who are busy on their work, family and other commitments.

\section{Pros and Cons of E-learning}

The modern teaching and learning system has changed with use of information and communication technologies [8]. Indeed, E-learning refers to the use of information and communication technology to enhance and support learning in higher education [15]. The enhancement of education system is due to the emerging of E-learning system these days. E-learning is providing more flexibility and ability to get information for the student at any place accessing the internet [2]. Higher educational 
institutes were largely adopting the E-learning strategy for distance education or online learning. Also the emerging technologies were helping to create teaching and learning materials that has assist the student learn themselves reading different E-learning material such as e-book, multimedia CDs and DVDs, tutorial videos, web based technology etc. And some of the universities were offering online education or distance education with the use of newly emerging technology i.e. E-learning technology which is helping for flexibility in learning. However E-learning has both pros and cons for the students. Due to innovation of new learning system called E-learning, it would lacks face to face interactions between teacher and students. Table 1 and Table 2 summarizes some of the pros and cons of E-learning [7].

Table 1: Pros of E-learning [7]

\begin{tabular}{|c|c|}
\hline Pros & Descriptions \\
\hline 1. E-learning saves costs & $\begin{array}{l}\text { Saves } 40-60 \% \text { of the expense of training by traditional } \\
\text { means. Savings include (1) travel expenses; (2) facilities } \\
\text { and supplies costs; (3) administrative costs; (4) salaries } \\
\text { and (5) lost opportunity costs. }\end{array}$ \\
\hline 2. E-learning improves learning & $\begin{array}{l}\text { E-learning uses learning technologies that assist stu- } \\
\text { dents and trainees towards learning. } \\
\text { The interactions between peers and instructors can } \\
\text { 'activate learners' } \\
\text { E-learning exposes learners to real-world data, which } \\
\text { saves learners time in searching information and also } \\
\text { assists learners analyzing large collections of data. } \\
\text { E-learning provides a more in-depth learning experi- } \\
\text { ence. }\end{array}$ \\
\hline 3. Extra advantages for learners & $\begin{array}{l}\text { - Learners can get the best instruction available. } \\
\text { - Training occurs "just in time". } \\
\text { - Learners set the pace and schedule. } \\
\text { - } \quad \text { Training adapts to better access to instructors. } \\
\text { - } \quad \text { E-learning produces positive effects. } \\
\end{array}$ \\
\hline 4. Extra advantages for instructors & $\begin{array}{l}\text { - Instructors can teach from different locations. } \\
\text { - Instructors travel less. } \\
\text { - } \quad \text { Course content can be dynamic. }\end{array}$ \\
\hline 5. Extra advantages for Organizations & $\begin{array}{l}\text { - E-learning delivers high-quality training, including } \\
\text { training around the globe without travel. } \\
\text { - E-learning creates valuable learning resources. }\end{array}$ \\
\hline
\end{tabular}

Table 2 : Cons of E-learning [3]

\begin{tabular}{|l|l|}
\hline \multicolumn{1}{|c|}{ Cons } & \multicolumn{1}{c|}{ Descriptions } \\
\hline 1. More instructor effort required & $\begin{array}{l}\text { Instructors need more preparations, so that they can } \\
\text { answer learners' questions and clear their doubts. }\end{array}$ \\
\hline 2. More effort required by learners & $\begin{array}{l}\text { Online courses take } 20-40 \% \text { more time and effort } \\
\text { than traditional courses. }\end{array}$ \\
\hline 3. Conversion efforts take longer than expected & $\begin{array}{l}\text { Converting existing classrooms to online courses } \\
\text { has proven harder than many designers expected. }\end{array}$ \\
\hline
\end{tabular}




\begin{tabular}{|l|l|}
\hline 4. Distance learning is impersonal & $\begin{array}{l}\text { E-learning is often used as a type of distance learn- } \\
\text { ing and distance learning is "impersonal" due to } \\
\text { the lack of face to face contact. }\end{array}$ \\
\hline 5. Fear of the technology & $\begin{array}{l}\text { Many people feel technical problems are the main } \\
\text { barrier for E-learning. }\end{array}$ \\
\hline
\end{tabular}

\section{Impact of e-Learning in Nepal}

E-learning is basically suited for distance learning as it is more flexible with E-learning materials. As $80 \%$ of the total population of Nepal lives in a rural areas and has very low number of educational institute for higher education. Also with the shortage of educator and teaching material, students living in a rural areas face problem of education. Being large variation in topography in Nepal, it makes transportation difficult and costly. Also students living in a rural areas cannot afford to education in a city areas. So by this reason, E-learning appears to be an effect solution to this in rural Nepal where there are few school and colleges and teaching manpower [2]. With the use of E-learning materials at rural Nepal, any individual can get any information from any place. This will reduces the migration of rural people to cities seeking for higher education. As a result there will be more competent manpower so that they can uplift the rural areas of Nepal. Not only for the rural Nepal but also it will benefits the people living in urban Nepal. E-learning is the emerging technology that transform existing institute into new one meeting the challenge of new generation [7]. According to Dalayeva [13], "the main goal of E-learning technology is to ensure an equal access of all participants of learning process to the best available resources and technology". Adopting this newly emerging technology has become more supportive to educational institute for applying distance education providing educational services to students as they can learn or get information through accessing the internet [16]. As E-learning materials base of universities grew up, there is being set up condition for integration of distance education through internet based technology. Also approaching to this emerging technology of E-learning in Nepal, some of the school, colleges or universities offering flexible learning on optional courses and enabling access to the course resources [6].

Students with due some circumstances unable to attain the courses offered by educational institute on a schedule and they often leave in the mid. But with the increased flexibility, learning system has offered online courses helping the students for accessing the lectures or other courses at their own schedule. Nowadays, with the advancement of technology many tutorials can be made relating to training or for education in the form of audio, video, graphic, simulation, animation, e-book etc [6]. So, these days students in Nepal get themselves learning seeing the tutorials at home or any where accessing the internet. The components of E-learning are helping to enhance traditional face to face classroom learning. E-learning comparatively with conventional learning reduces the time to locate the information, also help students finding information in a less time through online resources accessing internet.

\section{Challenges of e-Learning in Nepal}

With the past of decades, higher educational institutes were facing more challenge by the increasingly global, digital and dynamic environment. There were certain barriers associated with the E-learning these days and the core challenge is to overcome these barriers [2]. Indeed, increased competition of education in higher educational institute have encouraged to increase educational status and scopes with newly emerging technologies [17]. Lack of human resource 
(skilled manpower) in rural areas of Nepal, there were low level of literate people comparing urban areas of Nepal. People of rural Nepal do migration to the city areas for higher education. So the core challenge of this era is to enhance the education system approaching to E-learning strategy and providing online learning services or distance education to students globally to all areas of Nepal. The most of information available are in English languages that cause language barrier as people from rural areas of Nepal cannot understand these languages and cannot access computer too. Internet services provider of Nepal are still failing to provide services fully to rural areas of Nepal. So there requires improvement of all these barriers for the enhancement of E-learning in Nepal [2].

Indeed, people from rural areas of Nepal were still approaching to face to face learning strategy due to lack of technology. So different technologies should be used diversely to all areas of Nepal providing them the useful information regarding the newly emerging technologies and its usefulness. All the barriers like cost, language, lack of human resource, lack of ICT tools etc inhibited the growth of E-learning. Eliminating all the above mentioned barriers will definitely help upgrading the status of the people living in both rural and urban areas of Nepal. Since E-learning is the effective tool for teaching or training and for learning purposes, it will definitely upgrade the status of education system. Stoffregen et al. [18] explains that "E-learning in the public sector often refers to blended information and communication technology (ICT) - supported training, meaning that online sessions are combined with traditional face-to-face seminars". Most courses were offered through E-learning with the increasing competitiveness as well as saving cost. As rural people with lack of skills and knowledge do engage in E-learning practices, there required familiar with the online practices of learning for proper adoption of knowledge. With the rapidly changing world with digital competency, there is a challenge of adopting all digital teaching and learning concentrating advance contents development and this digitally changing world requires digital platform of learning with the E-learning. Al-Hassan [1] explains that the main challenge is to provide efficient and adaptive E-learning system to the learner. To get achievement on efficiency of E-learning, E-learning systems can be modeled as the directed graph and each node to be represented as learning objects where as learning objects includes concept, object, an image or an audio session [1]. E-learning is being widely adopted and used in developed areas, there is ease of accessing to get information however there is no easy of accessing to get information for students living in developing areas. So there is a challenge of providing the infrastructure of learning taking account of internet connectivity and making availability of E-learning materials.

\section{Conclusion}

From the studies of the state of education system with E-learning, we find that E-learning being the most desired, effective and cheaply available tools for learner, it is more resourceful for learner as they can acquire more information accessing the internet. With the advancement of technology, many educational institute were offering online learning or distance education using E-learning materials. Those people who were unable to give full time for learning in a higher educational institute due to their own circumstances, E-learning has made easy learning for them by themselves using different web based technologies or seeing the tutorials in a computer or mobile on accessing the internet. As many universities of Nepal now offering the distance education with internet technologies, students were getting more opportunities of multiple option of flexible learning. Comparing to urban areas of Nepal, rural areas of Nepal were still failing to get more facilities of learning and acquiring knowledge being the certain barriers of learning. So, all these barriers should be eliminated to get improvement of E-learning. The two leading universities of Nepal, 
Kathmandu University and Tribhuvan University of Nepal were offering distance education for bachelor degree and master degree. Also the Kathmandu University offering MOOC for online courses that will help people learning with flexible option. Learning management system or course management system is the type of E-learning which are now broadly adopted by the universities. Due to increasing use of E-learning strategy in education and training, E-learning markets are day by day up growing increasingly. And due to this largely availability of E-learning materials, the higher educational institute broadly adopting the E-learning strategies these days.

\section{References}

[1] Al-Hassan A (n.d), A comparison of e-learning and traditional classroom teaching: Petra University. Petra University, Retrieved from https://www.uop.edu.jo/download/Research/ members/67_1262_Ahma.pdf

[2] Aryal R and Aryal A (2007), E-learning in Nepal : Prospects and Challenges. Retrieved from http://nascoit.org.np/published_journals/?s=E-learning-in-Nepal-Prospects-and-Challenges.pdf

[3] Ashraf S, Khan T and Rehman I (2016), E-learning for secondary and higher education sector: Survey. (IJACSA) International Journal of Advanced Computer Science and Applications, 7(9): 275-283.

[4] Asian Development Bank (2005), International workshop on improving e-learning policies and program. Retrieved from https://www.adb.org/sites/default/files/publication/27953/improvinge-learning-policies.pdf

[5] Baturay M (2015), An overview of the world of MOOCs. Turan Güneş Bulvarl 648. Cadde İpek University Campus, Ankara, 06550, Turkey, Procedia - Social and Behavioral Sciences, 174: $427-433$.

[6] Bischel J (2013). The state of E-learning in Higher Education: An eye toward growth and increased access. EDUCAUSE Center for Analysis and Research. Retrieved from https://www. educause.edu/ecar

[7] Chang V (2015), Review and discussion: E-learning for academia and industry. School of Computing,Creative Technologies and Engineering, Leeds Beckett University, Leeds, U.

[8] Dalayeva T (2013), The e-learning trends of higher education in Kazakhstan. 3rd World Conference on Learning, Teaching and Educational Leadership (WCLTA-2012).

[9] Digital Learning for Development. (2016), MOOC for Higher Education in Nepal. Retrieved from Digital Learning for Development website. http://dl4d.org/portfolio-items/mooc-forhigher-education-in-nepal/

[10] Docebo (2016), E-learning market trends and forecast 2017-2021. Retrieved from https://www. trainingpressreleases.com/media/30885/docebo-elearning-trends-report-2017-short.pdf.

[11] E-learning 101.(n.d), E-learning concepts, trends, application. Retrieved from https://www. talentlms.com/elearning/

[12] Hrastinski S (2008), Asynchronous and Synchronous E-Learning. EDUCAUSE Quarterly. 31(4) Retrieved from http://er.educause.edu/articles/2008/11/asynchronous-and-synchronouselearning.

[13] Manandhar R (2012), Implementing long tail of learning in e-learning. School of Engineering, Kathmandu University.

[14] Najmul Islam A (2015), E-learning system use and its outcomes: Moderating role of perceived compatibility. University of Turku, Finland.

[15] N D O, Salleh M and Iahad N (2012), E-learning methodologies and tools. (IJACSA) International Journal of Advanced Computer Science and Applications, 3(2): 48-52.. oi:http:// dx.doi.org/10.14569/IJACSA.2012.030208 
[16] Pangeni S (2016), Open and Distance learning : Cultural practices in Nepal. European Journal of Open, Distance and e-Learning 19 (2) ISSN 1027-5207. Retrieved from http://www.eurodl. org $/ ? \mathrm{p}=$ archives \&year $=2016 \&$ halfyear $=2 \&$ article $=718$.

[17] Pucciarelli, F, Kaplan, C and Galyen, A (2016), Competition and strategy in higher education: Managing complexity and uncertainty. Kelley School of Business, Indiana University. d o i : http://dx.doi.org/10.1016/j.bushor.2016.01.003

[18] Stoffregen J,... Moebs S (2016), Barriers to open e-learning in public administrations A comparative case study of the European countries Luxembourg, Germany, Montenegro and Ireland. University of Jyväskylä, Finland, Luxembourg Institute of Science and Technology, Luxembourg, Dublin City University, Ireland.

[19] Xiberta P and Boada I (2016), A new E-learning platform for Radiology Education (RadEd). Computer Methods and Programs in Biomedicine, S0169-2607(15)30089-4 doi: http://doi. org/10.1016/j.cmpb.2015.12.022

[20] Yanuschik O, Pakhomova E and Batbold K (2015), E-learning as a way to improve the quality of educational for international students. International Conference for International Education and Cross-cultural Communication. Problems and Solutions (IECC-2015), 09-11 June 2015, Tomsk Polytechnic University, 30: 147-155.. 